\title{
Structural reforms for growth and cohesion: lessons and challenges for CESEE countries and a modern Europe
}

EWALD NOWOTNY, DORIS RITZBERGER-GRUENWALD and HELENE SCHUBERTH (eds.)

Edward Elgar Publishing, UK, 2018, pp. 234

Book review by MAJA VEHOVEC*

https://doi.org/10.3326/pse.43.2.5

\footnotetext{
* Received: May 9, 2019

Accepted: May 13, 2019

Maja VEHOVEC, Ph.D.

University of Rijeka, Trg braće Mažuranića 10, 51000 Rijeka, Croatia

e-mail: maja.vehovec@uniri.hr

ORCiD: 0000-0001-6872-1136
} 
In order to prevent mistakes or the achievement of lower results in future structural reforms, three members of the Austrian National Bank - Ewald Nowotny, Doris Ritzberger-Gruenwald and Helene Schuberth - have edited a book about the achievements and failures of past structural reform policies. Judging from the book they published together in 2015, The Challenge of Economic Rebalancing in Europe, it seems that their collaboration is fruitful. Moreover, the collaboration between Nowotny and Ritzberger-Gruenwald was extremely productive from 2012 onwards with four monographs being published every second year. The newest book is dedicated to structural reforms, one of the three pillars - investments, structural reforms and fiscal responsibility - for promoting economic growth and creating more jobs. Although all the pillars are equally important, structural reforms are a sine qua non for all the others. The aim of the book is to answer how to shape a better future by promoting policies beyond liberalization and deregulation. This attempt adds value to the contemporary literature.

The book is structured in five parts with seventeen chapters and twenty-five contributors. The first part is dedicated to a modern understanding of structural reforms, the second to the contribution of technological change and innovation, the third to the distributional effects of reforms, the fourth to past and current reform strategies in Europe, and the fifth to the open question of what should be reformed - EU frameworks or EU countries? This book may be challenging for the reader, particularly one who wishes to cover the ground quickly, for the kind of contribution it makes cannot be presented simply. The main reasons are the diversity of written styles and the different perspective that emerges from each topic and/or authors' affiliation. Authors come from different institutions such as national banks, European Commission, EBRD, World Bank, research institutes and universities. Hence, their institutional knowledge, as well as their career positions, also influence their styles and their standpoints toward structural reforms. Some of these authors are researchers, some are professional analysts and some are members of the senior managements so that chapters range from typical journal papers to typical review papers and simply to professional opinions. The diversity of institutions and different professional perspectives are both an advantage and also an obstacle to correlating and aligning all the observations and opinions. Nevertheless, heterogeneity is more rewarding than homogeneity, particularly when topics like structural reforms are being dealt with.

The first part of the book starts with the editors' introduction of the aim and the description of each chapter. The book is oriented toward the role of structural reforms in the transformation of economic systems into more inclusive growth strategies instead of the usual recommendations for more deregulation, liberalization, and privatization. In addition, this book is more, but not exclusively, focused on the area of Central, Eastern and South-Eastern Europe (CESEE). And here, citizens from Croatia might become frustrated, as it is not given as an example of a country processing structural reforms. The country is mentioned only once, on page 186 , in the context of prime ministerial corruption. This is something that 
readers from Croatia have to face when looking at their country's international position and its possibilities of achieving growth that is more inclusive.

The first part of the book also includes an interesting EBRD prospective by its chief economist Sergei Guriev on the pre-crisis and post-crisis slowdown in the process of convergence in CESEE countries. He provocatively suggests that these transition countries are stacked in the so-called middle-income trap, without incentives for building institutions able to promote innovation-based growth. In addition, he wonders how much the lack of demand for reforms is due to loss of confidence in previous reforms, as research proves that inequality due to unfairness causes major obstacles in the way of further reforms. Therefore, the EBRD advocates the redesign of dimensions along with its new transition concept for a sustainable market economy. The focus should be on six qualities, meaning an economy has to be: competitive, well-governed, green, inclusive, resilient and integrated. Politicians may not be aware of these combination goals when raising the topic of the importance of growth at election time because this concept integrates left and right wing orientations. In addition to the topic of economic convergence, Georg Fischer from the Vienna Institute for International Economic Studies requests a stronger social dimension for the influence of the EU on the member states, especially when they are not in a situation to do it alone. He argues for social convergence in parallel with other efforts that are aimed at accelerating economic recovery and convergence in balancing between economic and social objectives. On the other hand, Sonja Puntscher Riekmann from the Salzburg Centre of European Union Studies questions the future of "building a deeper and more genuine EMU" as an engine of growth after the time of crisis, and the role of European Commission based on its so-called 2017 Reflection Paper. She agrees that the EU needs supranational organs, but wonders whether international treaties will be enough or whether the EU needs stronger constitutional settings.

The second part is dedicated to technological change and innovation as opportunities for growth across countries. Helena Schweiger from the EBRD proves that for CESEE, after the global financial crisis, only innovation in the private sector is a potential real contributor to productivity. However, there are many prerequisites for innovation-based growth. From the quality of institutions, macroeconomic stability, labour and financial markets to all the prerequisites that affect firms' abilities to innovate and create. The largest gap between CESEE countries and the advanced economies is in the capacity to create and use knowledge. There is no one-size-fits-all recommendation because in the bottom line innovation-driven growth needs formal and informal institutional changes. An outside view of Europe, through the lens of globalization, is given by Daria Taglioni from World Bank who sees the advantage of the EU single market in the creation of powerful digital ecosystems. Digital platforms need regulation and deeper integration with the rules of the EU. This vision is possible if national policies do not push firms away from global technological frontiers. The chapter about non-tariff measures by Mahdi Ghodsi, Julia Gruebler, Oliver Reiter and Robert Stehrer, from the 
Vienna Institute for International Economic Studies is a research article and thus quite different from the other chapters. They have proved that non-tariff measures are strongly responsible for trade restriction.

The third part is focused on the distributional effects of reforms. Orsetta Causa, from OECD, investigates the distributional implications of pro-growth policies such as the increase in government expenses on education or reduction in regulation. An especially interesting part is how reforms in each country have an impact on household income that spreads across the income distribution. The results show generalizations of structural reforms' impacts on economic growth and changes in inequality are not applicable to all countries. "The winner takes it all" model is possible only if the measures are sensitively designed and tailored in synergy for more inclusive growth. In this part, editors have also decided to include a typical journal article by Paul Ramskogler from the Austrian National Bank, about the labour market changes, unemployment, and wage growth. He argues that the contemporary labour market changes toward an increase in temporary contracts had a significant impact on the wage growth especially visible after the crisis. Research results are put in the context of the economic theory and the Phillips curve.

The third part of the book includes country cases dealing with past and current reform strategies in Slovakia, Hungary, Czech Republic and Poland. Authors from Slovakia, Hungary, and the Czech Republic are the central banks' governors whose reports are more (Hungary and Czech) or much less (Slovakia) subjective. Their reports are very similar to reports they are habitually give to the European Commission or European Central Bank through the lens of their own institutional positions. The chapters have an uneven structure and miss strong messages or recommendations for which the editors and reviewers are responsible. In the same part, a contribution by Pawel Strzelecki from the National Bank of Poland differs in the sense that he gives a very profound overview of one specific structural reform, of the pension system in Poland. He raises some interesting research questions but ultimately in all of them the core issue of any structural reform is "permanent short-run temptations to abandon the commitment to optimal long-term enhancements". Almost all CESEE countries are facing the same problem, which makes a reading of this chapter extremely educational and useful. His main finding is that reforms' sustainability depend on business cycles, political calendars, good advertising and a wide range of social commitments. An essential but not the only condition for the sustainability of pension reforms is a political consensus achieved in a democratic process. He identifies that pressure for reform of the pension system does not depend only on budget constraints but also on pro-cyclical fluctuations in the expected long-run economic outlook.

The third part ends with an overview of the political models to transition by Alina Mungiu-Pippidi from the Hertie School of Governance in Berlin who describes paths taken by transition from its historical first steps at the beginning of the 1990s. She argues that the main policies in the time of post-communism differed 
in the different countries and it is not possible to compare them with the same yardstick. The source of difference is not just a matter of types or sequences of reforms, but "simply in the objectivity and impartiality of those who were directing reforms". Therefore, she is inclined to support national politics in the building of democracy democracies along with Europeanization within the EU framework that "favours only certain tendencies".

The final, fifth part challenges readers by questioning if we need to reform the EU or EU countries. Laszlo Csaba from the Central European University in Budapest argues that it is difficult to find relevant arguments against the euro, especially for a small open economy, even with the rise of political Euroscepticism in the EU. He thinks that the eurozone framework is not a barrier to national adjustment in individual EU countries and that financial vulnerability is higher for those that remain outside of the eurozone. In contrast, Hubert Gabrisch from the Wiesbaden Institute for Law and Economics thinks that the EU framework needs to be reformed or improved by implementing an EU-specific central fiscal risk-sharing capacity as an overlay on the existing system. In addition, he proposes an EU stabilization fund for investment or an European unemployment insurance system. In the last chapter, Lucio Vinhas de Souza, Oliver Dreute, Vladimir Isalia and Jan-Martin Frie from the European Political Strategy Centre of the European Commission present evidence-based opinions in a simple and clear textbook style. Their conclusion is that nominal convergence can bring a country to the euro area, but then later everything depends on the country's ability to produce and implement sound policies for sustainable economic development. In addition, the member states' capacity for building institutions and competitiveness is mainly responsible for achieving real convergence. In that process, countries are financially constrained in the implementation of all the necessary policies and the Structural Reform Support Programme is usually insufficient. They advocate transferring new financial lines under the European Structural Investment Fund. This will be helpful for fostering the process of economic convergence in the EU, and for the resilience of the EMU.

This book contains such a variety of topics that everybody can find something of interest. However, the same level of research quality should not be expected in all chapters. It seems that this was not in fact the intention. Most important is the collection of differing opinions about, experiences of, and solutions for structural reforms aiming at future growth possibilities for individual countries within the EU cohesion framework. It seems that there is a united standpoint that the "best practices fits all" model should be discarded in favour of "country tailored" recommendations. However, different standpoints remain about the proper balance between EU framework reforms and national, country-level reforms. 